\title{
METROPOLISATION AND THE EVOLUTI ON OF SYSTEMS OF CITIES IN THE CZECH REPUBLIC, HUNGARY AND POLAND SINCE
} 1950

\author{
Natalia ZDANOWSKA \\ ${ }^{a}$ Université Paris 1 Panthéon-Sorbonne, UMR 8504 Géographie-Cités, Address: 13 rue du Four, 75006 \\ Paris, phone: +336950953 54, e-mail: nataliazda@gmail.com
}

Cite this article: Zdanowska, N. (2015). Metropolisation and the evolution of systems of cities in the Czech Republic, Hungary and Poland since 1950. Deturope, 7, 2: 45-64

\begin{abstract}
This article examines the evolution of systems of cities in the Czech Republic, Hungary and Poland since 1950, and especially since the fall of the Berlin Wall in 1989 when Central and Eastern European cities started to experience the process of metropolisation. This period corresponds to an intense globalisation of the economy which has been characterised by some researchers as an emergence of a world urban system. While the metropolises of formerly industrialised countries had already been strongly interconnected on a macro-regional level, Central and Eastern European countries took on the unique approach of prioritising relations directly at an international level. In addition to its highly exacerbated characteristics, the metropolisation in Central and Eastern Europe has been taking place within a substantially shorter time period in relation to other countries. This article investigates how these phenomena might have influenced the configuration of today's urban systems.

After presenting the methodology used to reconstruct urban agglomerations since 1950 until now, we examine the evolution of the Czech, Hungarian and Polish systems of cities by using several national databases. By analysing the changes in urban hierarchy and new urban patterns, we can stress that after 1989 the metropolisation has rather contributed to raise the predominance of the capital city in the urban systems than to diminish inequalities between the cities.
\end{abstract}

Keywords: systems of cities, the Czech Republic, Hungary, Poland, Central Europe, metropolisation, urban hierarchy, urban patterns

\section{INTRODUCTION}

The process of metropolisation can be defined as a concentration of population and major economic decision functions in metropolises, in particular at the world-system level (Sassen, 1991; Taylor, 2001; Vandermotten et al., 2010). Metropolises of formerly industrialised countries, playing the role of "gateways of globalisation" (Bretagnolle et al., 2011), have already been competing between each other to attract the most qualified and dynamic activities (Pumain, Rozenblat, 2007). Indeed, we consider the structure of urban systems as, "the product of a complex evolutionary process, involving mainly a competition between cities” (Bretagnolle et al., 1998). 
In Central and Eastern Europe ${ }^{1}$, metropolisation at the world-system level was restricted during the socialist period and has only been taking place since 1989 (Dostál, 2008; Pyka, 2011). Urbanisation in the state socialist systems was characterised by an "overwhelmingly industrial character" of cities largely located in the countryside, thus turning villages to medium size cities (Enyedi, 1998). This context leads to questioning of the fate of these cities during the transformation period after 1989 and the role of the larger cities, put aside in favour of the medium-sized under socialism. The period since 1989, corresponding to an intense globalisation of the economy, has also been characterised by the process of city networking at a worldwide level (Michalet, 2007). Metropolisation in Central and Eastern Europe has been exacerbated by being directly launched on a worldwide scale. In addition, it has been taking place in a subsequently shorter period of time than in the liberal system countries (Pyka, 2011).

At the level of national systems of cities or the "set of cities interdependent in their evolution process" (Pumain, 2007), metropolisation generally concerns the capital cities, although sometimes it affects other cities of important size as well (Cattan, Saint-Julien, 1998). Today, Czech, Hungarian and Polish cities are a long way from playing a role as global cities such as New York, Tokyo or London (Sassen, 1991). However at least eight ${ }^{2}$ Polish cities have metropolitan functions in the sector of finance (Bourdeau-Lepage, 2004), IT technology, industry, services, administration and international politics (Pyka, 2011). One ${ }^{3}$ city in Hungary and three ${ }^{4}$ in the Czech Republic have these characteristics. These new metropolitan functions are certainly the simultaneous result of implementation of large firms but also of new urban dynamics since 1989. How did this exacerbated metropolisation influence the evolution of the systems of cities in the Czech Republic, Hungary and Poland?

The hypothesis of this article proposes that metropolisation since 1989 has rather contributed to raise the predominance of the capital city in the urban systems than to diminish inequalities between the cities.

\section{METHODS}

Urban hierarchy of Czech, Hungarian and Polish system of cities will be evaluated by analysing databases on LAU2 populations from 1950 until 2002, specifically referring to

\footnotetext{
${ }^{1}$ Understood in this article as post-socialist countries part of the European Union since 2004.

${ }^{2}$ Warsaw, the Katowice or Upper Silesia Conurbation, Cracow, Poznań, Gdańsk-Gdynia-Sopot, Wrocław, Łódź, Lublin (OECD iLibrary).

${ }^{3}$ Budapest (OECD iLibrary).

${ }^{4}$ Prague, Brno and Ostrava (OECD iLibrary).
} 
those produced by the Czech Statistical Office (Český statistický úrad), the Hungarian Central Statistical Office (Központi Statisztikai Hivatal) and the Central Statistical Office of Poland (Główny Urząd Statystyczny). The Urban Morphological Zones of 2000 database produced by the European Environment Agency (EEA, 2002), will serve for urban morphological agglomeration construction since 1950 by applying the "retropolation" methodology. This methodology consists of "reconstructing data from the past based on currently defined criteria" (Bretagnolle, 2009, p. 60).

\section{The construction of an urban agglomeration database since 1950 in the Czech Republic, Hungary and Poland}

The definition of a city is variable, open to interpretation amongst countries in Europe. Some have adopted approaches that could be defined as juridical (based on legal status delivery); quantitative (statistical threshold population); morphological (more or less concentrated character of housing); and later as functional (related to commuting to work) (Bretagnolle, 2009). The definition of a city in the Czech Republic, Hungary and Poland is juridical. In the Czech Republic, a municipality can be afforded city rights to become a město, if it has a least 3000 inhabitants. However some smaller municipalities obtained city status because of their historical backgrounds, and since 2006 a special category městys was instituted to distinguish historical villages (Parliament of the Czech Republic, 2000). In Hungary, a village can enter candidacy for the status of város (city), delivered by the Minister of Internal Affairs, if it falls within a set of public service and infrastructure constraints. Becoming a city can bring many fiscal advantages. Therefore many villages compete to obtain their city rights (Hungarian Central Statistical Office, 2012) and many were successfully bestowed with them after $1989^{5}$, often for political reasons. In Poland the status of a city (gmina miejska) is delivered by the Council of Ministers (Ustawa o Samorządzie Gminnym z dnia 8 marca 1990 r. $^{6}$ ). Different criteria relating to size and the state of infrastructure are taken into account, although the decision is often based on very flexible and subjective arguments (Zborowski, 2009).

To counteract all of these potentially problematic juridical definitions, which do not permit the analysis of comparable entities for the given countries, it seems justifiable to consider

\footnotetext{
${ }_{6}^{5}$ Commentary issued from an interview with professor Zoltan Kovács in November 2014.

${ }^{6}$ Project of law on municipal administration of 8th March 1990, Council of Ministers of the Republic of Poland, 1990.
} 
further definitions based on morphological or functional criteria, relatively corresponding to the concept of agglomeration and functional area (Bretagnolle, 2009).

A few databases on functional areas have been generated in Europe, among those one that is entitled Functional Urban Areas which is based on commuting between the place of residence and the place of work (Peeters, 2011). National experts have identified 48 FUA in Poland, 25 FUA in the Czech Republic and 77 FUA in Hungary (ESPON project 1.4.3, 2007). The problem with this approach is that the important extent and size of FUAs tends to exclude small cities as they are often integrated to a given FUA. This presents a challenge while working on and analysing the evolution of urban hierarchy. In addition, the databases have generally been constructed only since 2000 , which does not permit the inclusion of any real sense of historical perspective. For this reason the concept of agglomeration seems to be more advantageous.

Two types of morphological criteria permit the definition of an agglomeration: the continuous built-up area and the minimal density (Bretagnolle, 2009). Some of the databases rely on a minimal density criteria as in Cities (Dijkstra, Poelman, 2012), or in the Morphological Urban Areas (MUA) (Vandermotten et al., 1999). The Urban Morphological Zones of 2000 (UMZ 2000) of the European Environment Agency (EEA, 2002) are defined with the context of a continuous built-up area criteria. These UMZ are only defined for the year 2000 which involved the necessity of constructing a methodology to retropolate them, and more precisely to apply to the previous years the rules of construction established for 2000. This methodology is part of a work conducted in the TRADEVE project framework within the UMR Géographie-Cités and the ESPON DataBase project.

The Urban Morphological Zones of 2000 database is a very solid working tool, which can be applied in Central and Eastern European countries, where no national morphological database has been yet produced (Guérois et al., 2012).

Taking as a starting point the coverage in 2000 , we have constructed a multi-communal agglomeration definition in the Czech Republic, Hungary and Poland, combining a contiguous built-up area and a minimum density or population threshold of population criteria $^{7}$. The delimitations of the Czech, Hungarian and Polish UMZ have been retropolated

\footnotetext{
${ }^{7}$ For the moment two criteria of minimal density and population are investigated for the Czech Republic, Hungary and Poland, but also for the rest of Central and Eastern Europe as a part of the thesis.
} 
for the period until 1950 using temporal series on population of the administrative units composing them. ${ }^{8}$

Figure 1 Retropolation of Urban Morphological Zones of 2000: theoretical example

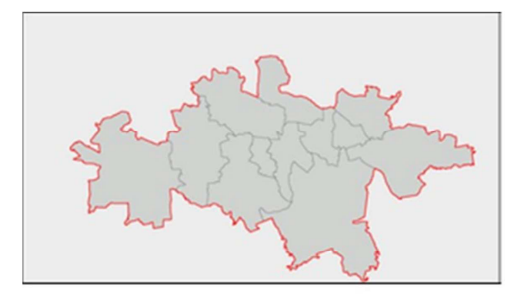

Time $t$

One UMZ in 2000

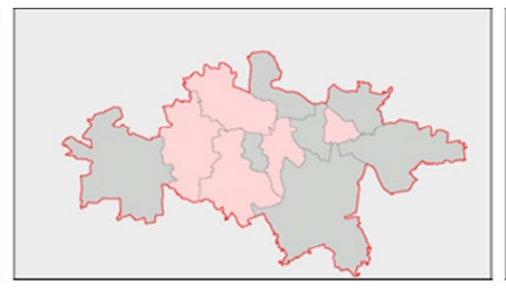

Time $\mathrm{t}-1$

Selection of urban LAU2s in 1950

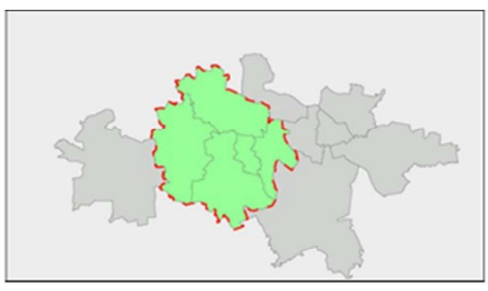

Time t-1

Aggregation of urban LAU2s in one $\mathrm{UMZ}$ in 1950

An important issue of this retropolation is to choose the most appropriate criteria to aggregate the LAU2 within a UMZ. The UMZ 2000 database has been constructed according to a distance criteria of a maximum of 200 meters between the build-up areas (EEA, 2002). This maximal spacing out of 200 meters is used by numerous European countries (Le Gléau et al., 1996) such as France in the case of "unités urbaines" (Le Gléau et al., 2006), and also Denmark and Sweden (Bretagnolle et al., 2012). Consequently, we have also selected it regarding the Czech Republic, Hungary and Poland. Nevertheless the definitive choice between minimal density and population threshold has still not been undertaken and as such is under investigation. We have tested different possible parameters: some databases recommend applying a minimal population threshold of 10,000 inhabitants (Moriconi-Ebrard, 1994), 20,000 (Vandermotten et al., 1999) or 50,000 habitants (Parr, 2007), other databases are constructed upon a minimal density criteria of 650 inhabitants per $\mathrm{km}^{2}$ as in the case of the FUA (Peeters, 2011). For this reason, several versions of the Czech, Hungarian and Polish databases have been generated and submitted for expertise analysis. For the moment, the criterion of a threshold of 10,000 inhabitants leads to relevant and appropriate results for the three countries according to Czech, Hungarian and Polish specialists ${ }^{9}$ (Fig. 2, 3, 4).

\footnotetext{
${ }^{8}$ The limits of the Czech, Hungarian and Polish UMZ in 2000 have been retropolated in time back until 1950, using a time series on population of the administrative units composing them. More precisely it has consisted in selecting the Czech, Hungarian and Polish LAU2 situated in the 2000 envelopes of the UMZ, and subsequently make appear their population or density for the years since 1950 corresponding to the census dates, and aggregate into one UMZ all those verifying the chosen criteria.
}

${ }^{9}$ Based on interviews during fieldworks in 2014-2015 with professors P. Dostál, M. Hampl, E. Kiss, T. Komornicki, Z. Kovács, G. Lux, Z. Gál, P. Śleszyński, G. Węcławowicz and A. Zborowski. 
Figure 2 Retropolated Urban Morphological Zones for the Czech Republic with a criterion of a 10,000 inhabitants minimal threshold

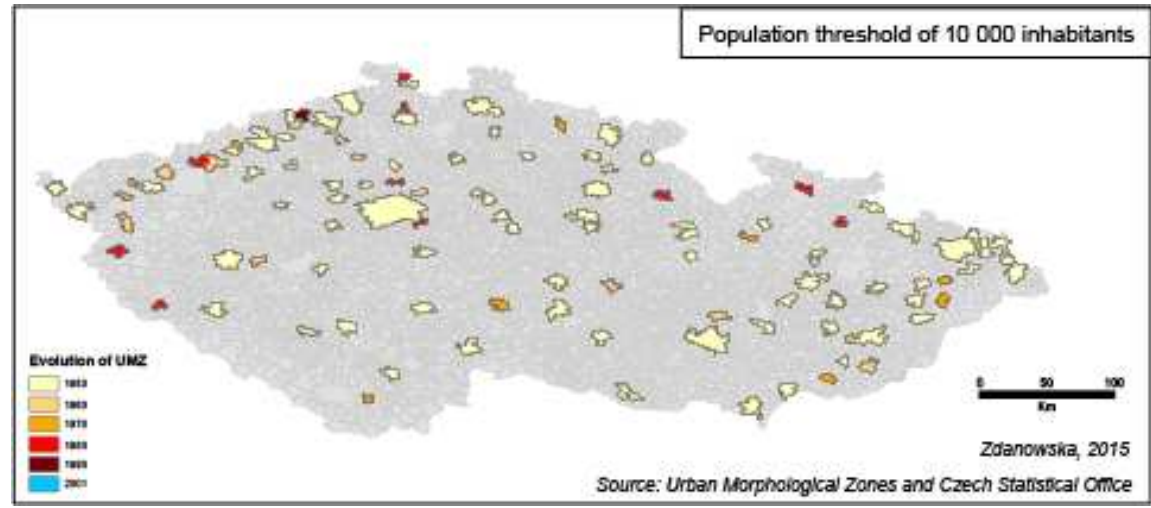

Figure 3 Retropolated Urban Morphological Zones for Hungary with a criterion of a 10,000 inhabitants minimal threshold

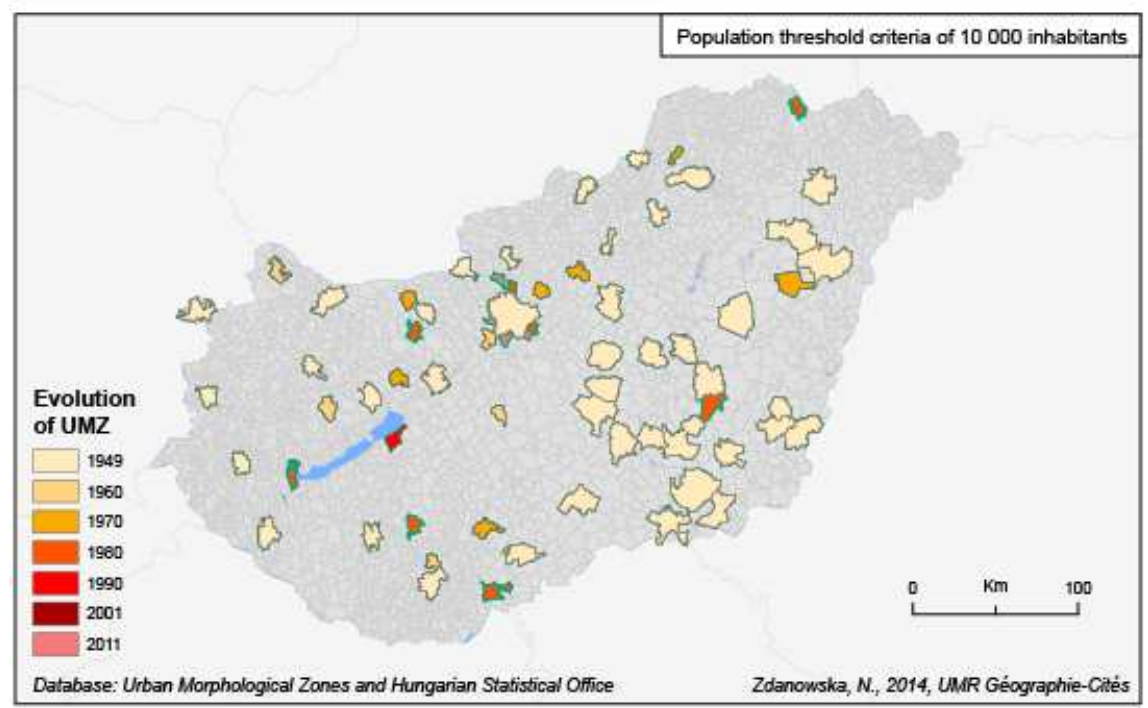


Figure 4 Retropolated Urban Morphological Zones for Poland with a criterion of a 10,000 inhabitants minimal threshold

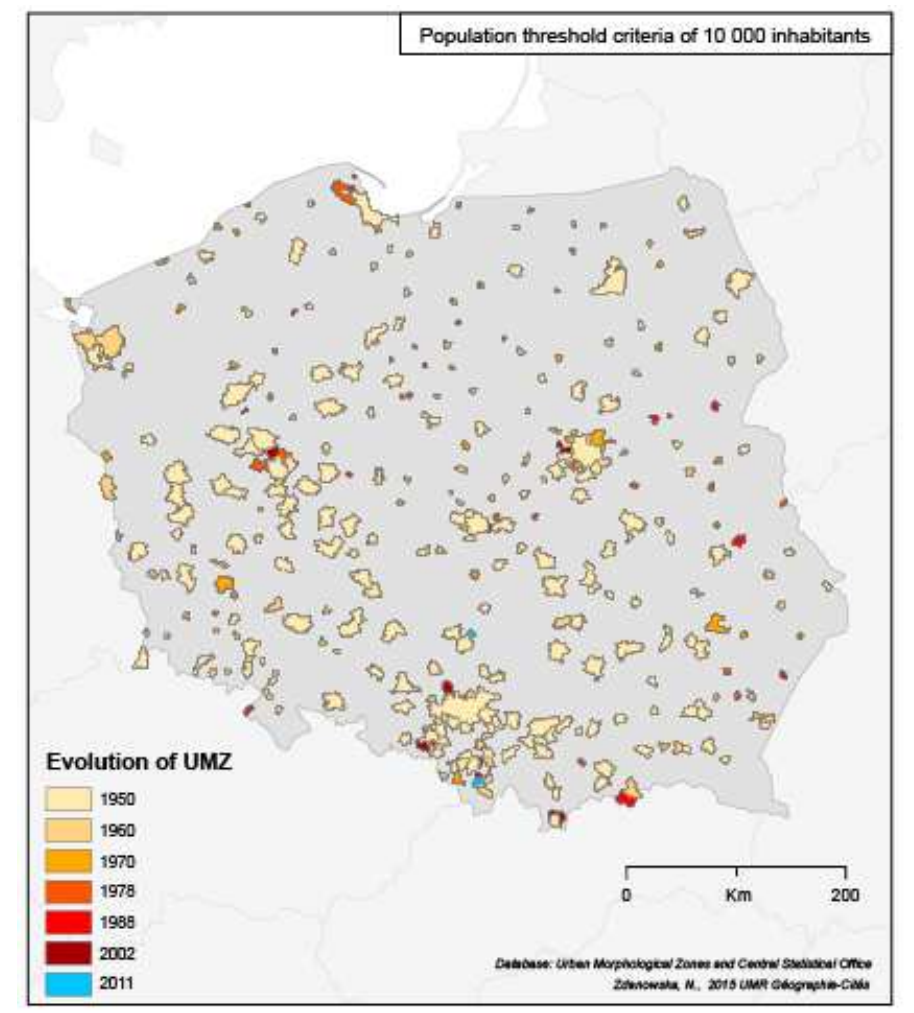

In the case of Poland we have additionally initiated some historical expertise on several large cities in Poland as Warsaw, Poznań and the Upper Silesian Conurbation.

An initial type of analysis consisted of observing the urban development along the railway transport axes via a personal analysis based on train timetables of Warsaw's suburban railway lines in 1950, 1960, 1970, 1978, 1988 and 2002 issued from the archives of the Polish National Railway company PKP.

A second type of analysis consisted of comparing the year in which the locality obtained the official administrative status of a city and the moment when the same locality entered the UMZ according to the retropolated database. Indeed the moment when the government delivers municipal rights to a rural commune, reflects certain dynamism and a sufficient development of its urban infrastructure (Jakóbczyk-Gryszkiewicz, 1998).

The results of both analysis revealed strong arguments toward a more realistic version of the database with a minimal population threshold of 10,000 inhabitants ${ }^{10}$.

\footnotetext{
${ }^{10}$ Other verifications must be done on other cities.
} 


\section{RESULTS}

\section{The evolution of urban hierarchy since the $1950 \mathrm{~s}^{11}$}

A first step in analysing urban hierarchy consisted of representing the distribution of the city sizes in rank-size graphs, plotted with a bi-logarithmic scale. Then this distribution has been adjusted by a regression line to measure the evolution in time of the slope's absolute value. In fact, compared in time, this slope is an indicator measuring the intensity of the contrasts between the sizes of cities and by consequence reflects the urban population concentration (Moriconi-Ebrard, 1994).

Rank-size distribution graphs and slopes of the regression lines for the entire period have been generated (between 1950-2001 in the case of the Czech Republic, 1949-2011 for Hungary, and 1950-2002 for Poland). Then an analysis of the urban primacy has been done by dividing the population of the two largest cities of the distribution of successive ranks (Bretagnolle et al. 2007).

Figure 5 Rank-size distribution graphs for the Czech Republic in 1950 and 2001 and the evolution of the slope values of the regression lines between 1950 and 2001
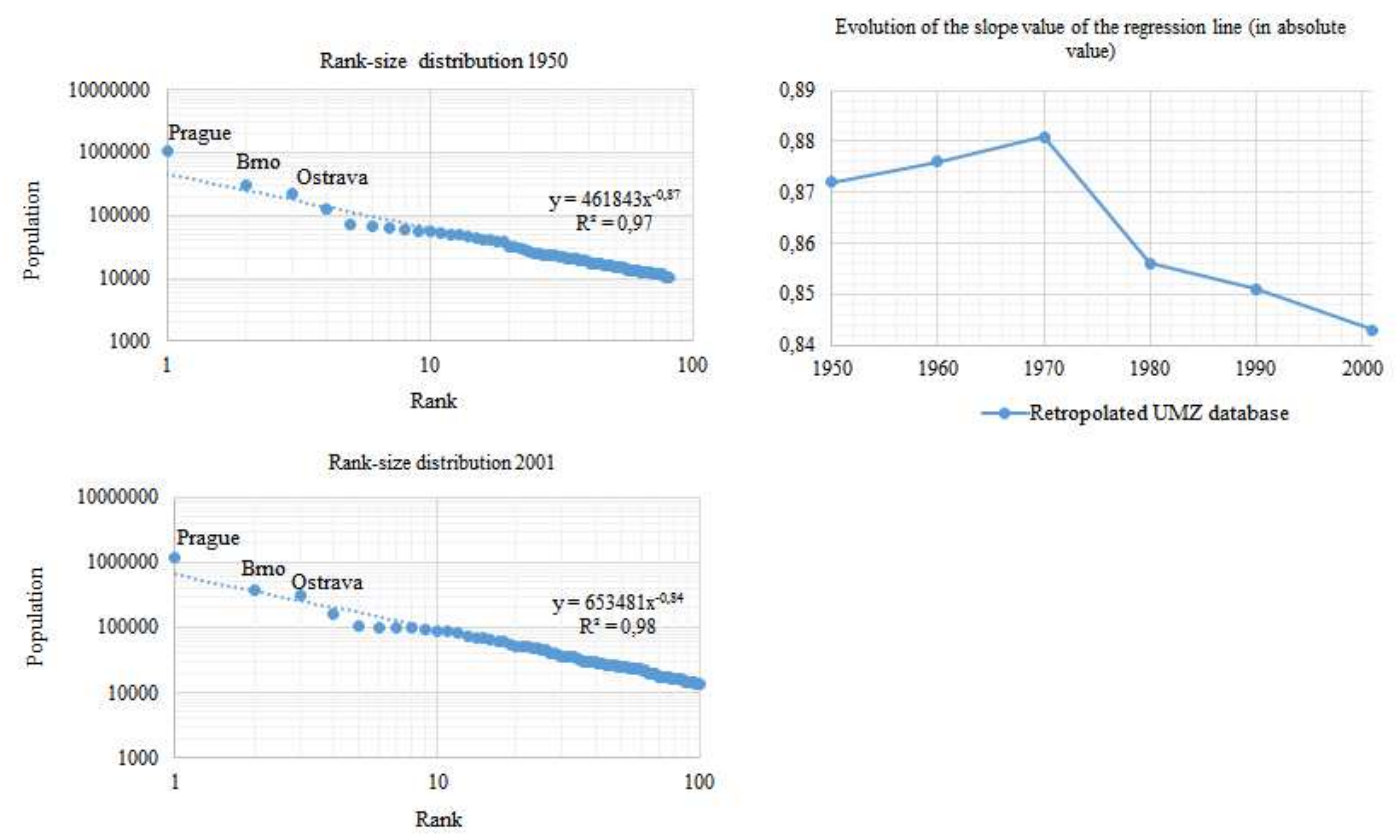

Figure 5 shows a predominance of the capital-city Prague over the rest of the urban system. Indeed in 2001, the first city Prague was populated by 1169106 inhabitants and the second city Brno by 376172 inhabitants. This observation refers to the capital city effect (Dostál,

\footnotetext{
${ }^{11}$ For all the following analysis a 10,000 population threshold version of the retropolated UMZ databases has been used for the calculations, but remains under investigation within the Ph.D. thesis. For the Czech Republic and Poland census population data starts from 1950 and for Hungary from 1949.
} 
2008) inherited from the pre-communist period's regional development. In spite of intensions to decentralise the economic activity, the main administrative and political power remained in the hands of the capital city, which has its impact still today in the majority of Central and Eastern European countries (Dostál, 2008). Jiři Musil has indeed predicted that at the international level, urban hierarchy will rise in Central Europe especially due to the widening weight of the capitals in national systems (Musil, 1993).

Nevertheless, the decreasing slope value of the regression line in figure 5 since 1970 permits us to conclude that a tendency of slight decrease was prevalent regarding hierarchy in the Czech urban system, which accelerated since 1990. Indeed the concentration tendencies, which corresponded to the hierarchization process, were significantly dynamic between 1870 and 1970 - an industrial era, and then followed by a relative stagnation. This latter tendency is due to administrative changes (urban districts were united with rural districts) and an important growth of towns populated by 10,000-20,000 inhabitants especially between 1950 and 1991 (Hampl et al., 1999). These changes may have an impact on our rank-size distribution.

In addition the acceleration of the loss of population in the capital city Prague in relation to Brno can be partly explained by the suburbanisation and commuting phenomena (Ouředniček et al., 2011), making the centre of Prague less populated.

Figure 6 Rank-size distribution graphs for Hungary in 1949 and 2001 and the evolution of the slope value of the regression line between 1949 and 2001
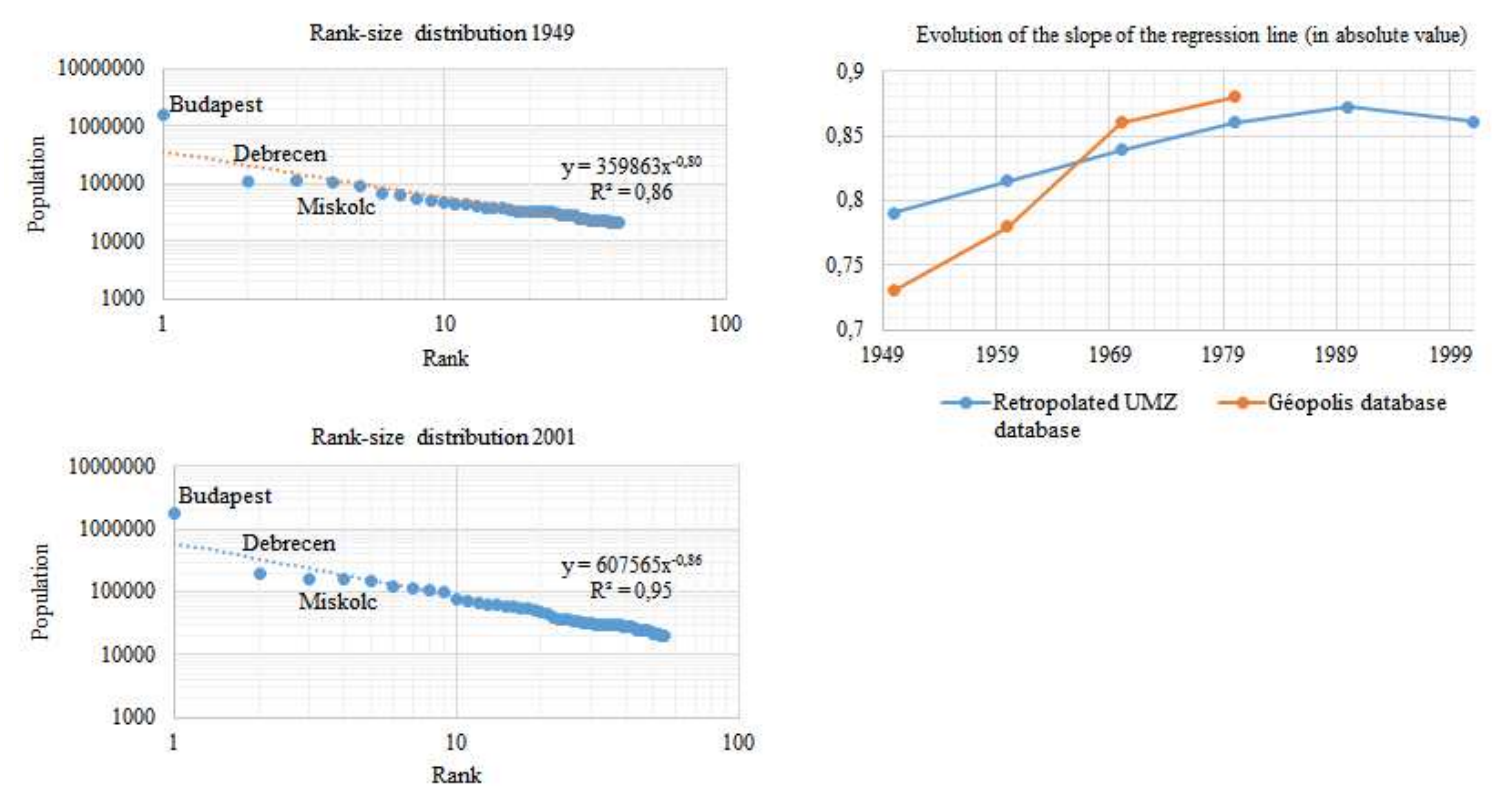
The analysis of the rank size distribution in Hungary reveals that the capital city effect is even stronger in the Hungarian system of cities that in the Czech case. In fact in 2001, Budapest was populated by 1909214 inhabitants according to the retropolated UMZs and the second city Debrecen by 198905 inhabitants. The gap between the capital city and the second city is even wider than in the Czech Republic, which makes the Hungarian urban hierarchy very high.

When focusing on the evolution of the slope of the regression line, an interesting result develops concerning the rising urban hierarchy as the coefficient grows from 0,79 to 0,87 between 1950 and 1990, followed by a slight drop to 0,86 in 2001. The rising hierarchy is also confirmed by the Géopolis database ${ }^{12}$ (Moriconi-Ebrard, 1994). It would suggest that in spite of the socialist equalisation period, the predominance of the capital in the system of cities was highly important and the centralisation of administration was predominant (Dostál, 2008). Therefore the decentralisation of industry throughout the territory during the communist period was not an entire success as Budapest remains today a leading dominant unit in the national city-system with a growing regional polarisation (Kovács, 2004).

Figure 7 Rank-size distribution graphs for Poland in 1950 and 2002 and the evolution of the slope value of the regression line between 1950 and 2002
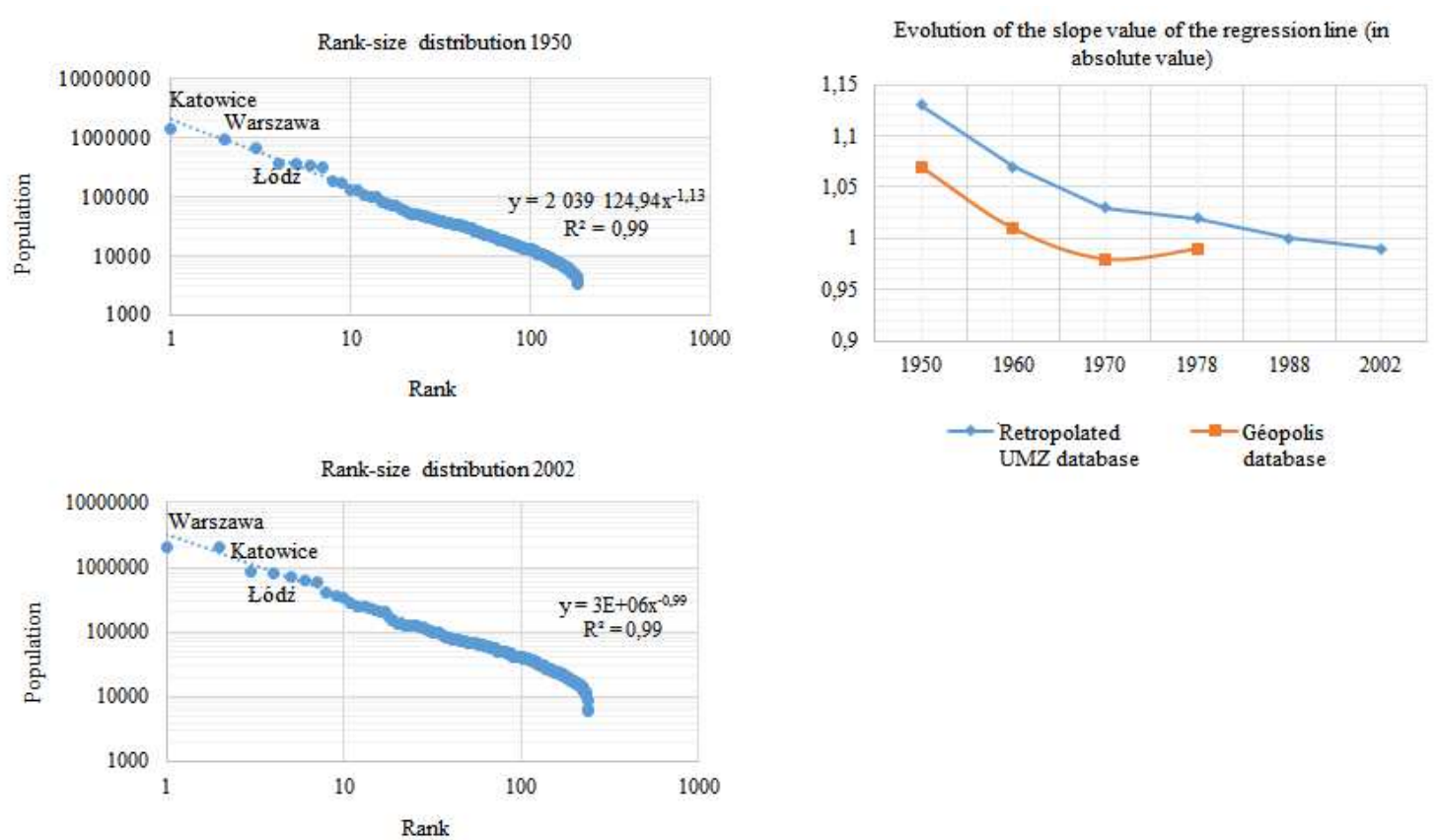

${ }^{12}$ The data in this form was available until 1980 (Moriconi-Ebrard, 1994). 
The results for Poland show an absence of 'macrocephaly' in the system of cities. In 2002, the first city's population (Warsaw) was 2027657 inhabitants and the second city (the Katowice or Upper Silesia Conurbation) was populated by 1990877 inhabitants. Additionally a persistence between 1950 and 2002 of secondary cities can be observed, as it is the case of Łódź and the Katowice Conurbation ${ }^{13}$ (Pyka, 2011).

In figure 7, a remarkable result concerns the drop of the absolute value of the coefficient of the slope between 1950 and 2002 from 1,13 to 0,99 . This reflects a process of re-equilibration of population with a passage from a high contrast between cities to a fairly hierarchized system. The coefficients of the slope of the regression line in Poland from the Géopolis database (Moriconi-Ebrard, 1994) are also showing a diminishing trend between 1950 and 1980, which brings even more evidence and weight to our results.

Therefore, the cases of Hungary and the Czech Republic highlight evidence of an urban system characterised by macrocephaly where the capital city's population size predominates over the second's city population through time. However while the Czech system tends to be less and less hierarchized from as early as 1970, Hungary's system still presented growing inequalities between cities, although with a slight fall of hierarchy since the 1990s.

The urban system in Poland is characterised by an absence of macrocephaly. The urban hierarchy of cities seems to reveal a tendency towards less inequalities between cities. It has to be pointed out that even in recent years, the declining tendency is still persisting, although less rapidly than in the 1950 s.

\section{The evolution of urban patterns since 1950}

The average annual growth rate of the retropolated UMZ for Hungary, the Czech Republic and Poland, for the years 1950-1960, 1970-1978 and 1988-2002, has been mapped to interpret the spatial evolution of inequalities between the cities observed previously.

It is important to bear in mind that in the case of the three investigated countries of Central Europe, prior to 1990, migration was strictly controlled and restricted within Central and Eastern Europe. The shift to a market economy from the 1990s onwards enhanced a migration flow of a different type: from labour mobility through transitory migration to the forced migration of asylum seekers and refugees (Kaczmarczyk, Okólski, 2005).

\footnotetext{
${ }^{13}$ According to the Central Statistical Office this conurbation is composed of 19 cities (Katowice, Sosnowiec, Gliwice, Zabrze, Bytom, Ruda Śląska, Tychy, Dąbrowa Górnicza, Chorzów, Jaworzno, Mysłowice, Siemianowice Śląskie, Tarnowskie Góry, Piekary Śląskie, Będzin, Świętochłowice, Knurów, Mikołów, Czeladź).
} 


\section{A. The Czech Republic}

Figure 8 Average annual growth rate of the Czech retropolated UMZ of more than 10,000 inhabitants between 1950 and 2001
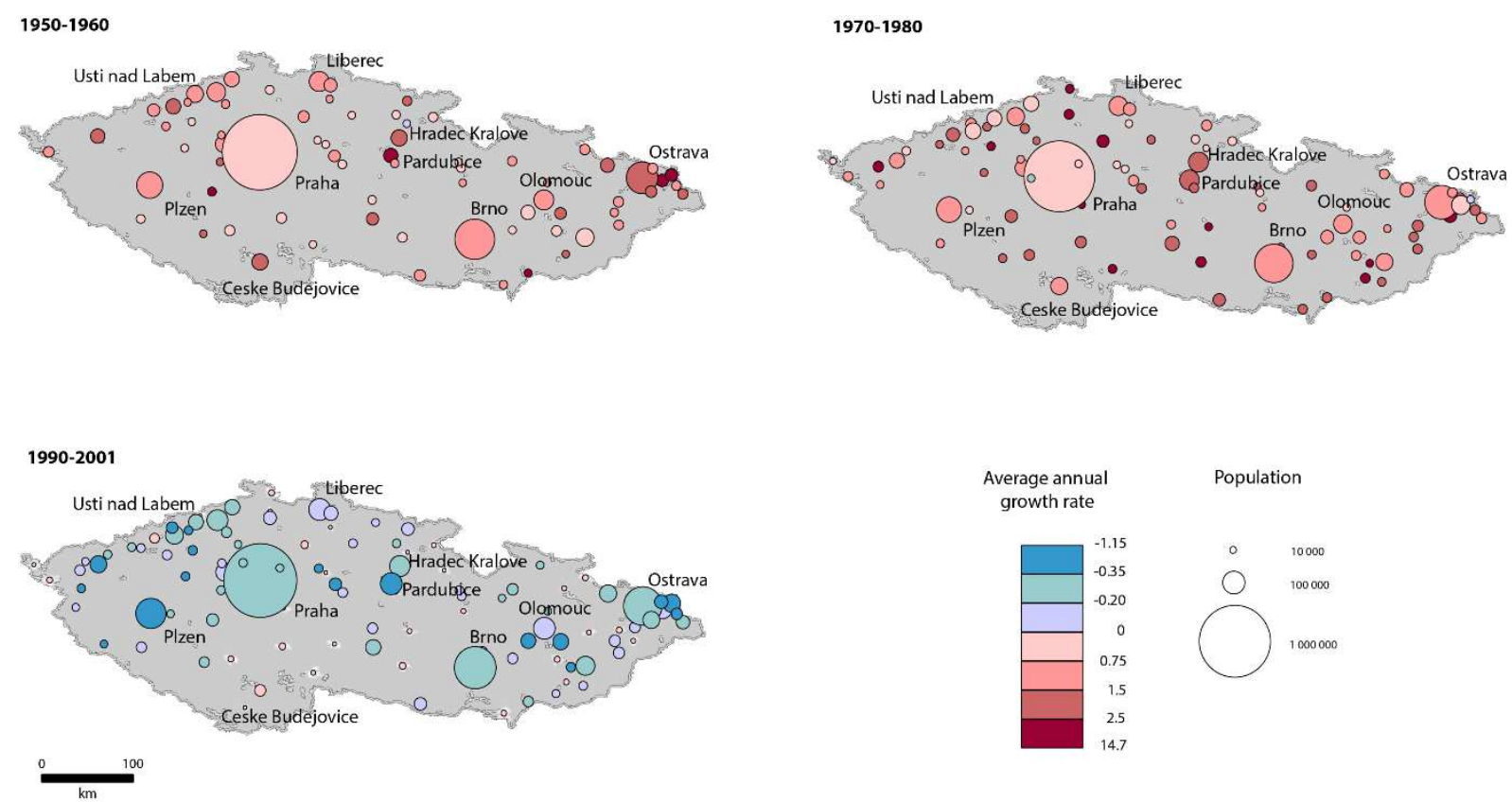

Source: Urban Morphological Zones and Czech Statistical Office.

These maps reveal that the majority of cities are closely located to the northern border of the country. Additionally we can point out an important decline of the average annual growth of cities especially between 1990 and 2001. These negative growth rates are due to the important outflows from the Czech Republic, which caused population loss, especially among citizens of a young working age (Gesano, Heins, 2008). Indeed, a very important number of Czechs left the country between 1991-1993 seeking better employment opportunities (Drbohlav, 2003). After 1993, migration became less popular as opportunities to develop new businesses increased (Drbohlav, 2003). Some cities passed through a period of population loss in the 1990s as a result of the decline of old industrial regions as is the case of Ostrava (Sucháček, 2005). Moreover, major displacements of population between Czech and Slovak cities after the dissolution of Czechoslovakia took place after 1993 (Cattan, Grasland, 1996). 


\section{B. Hungary}

Figure 9 Average annual growth rate of the Hungarian retropolated UMZ of more than 10,000 inhabitants between 1949 and 2001.
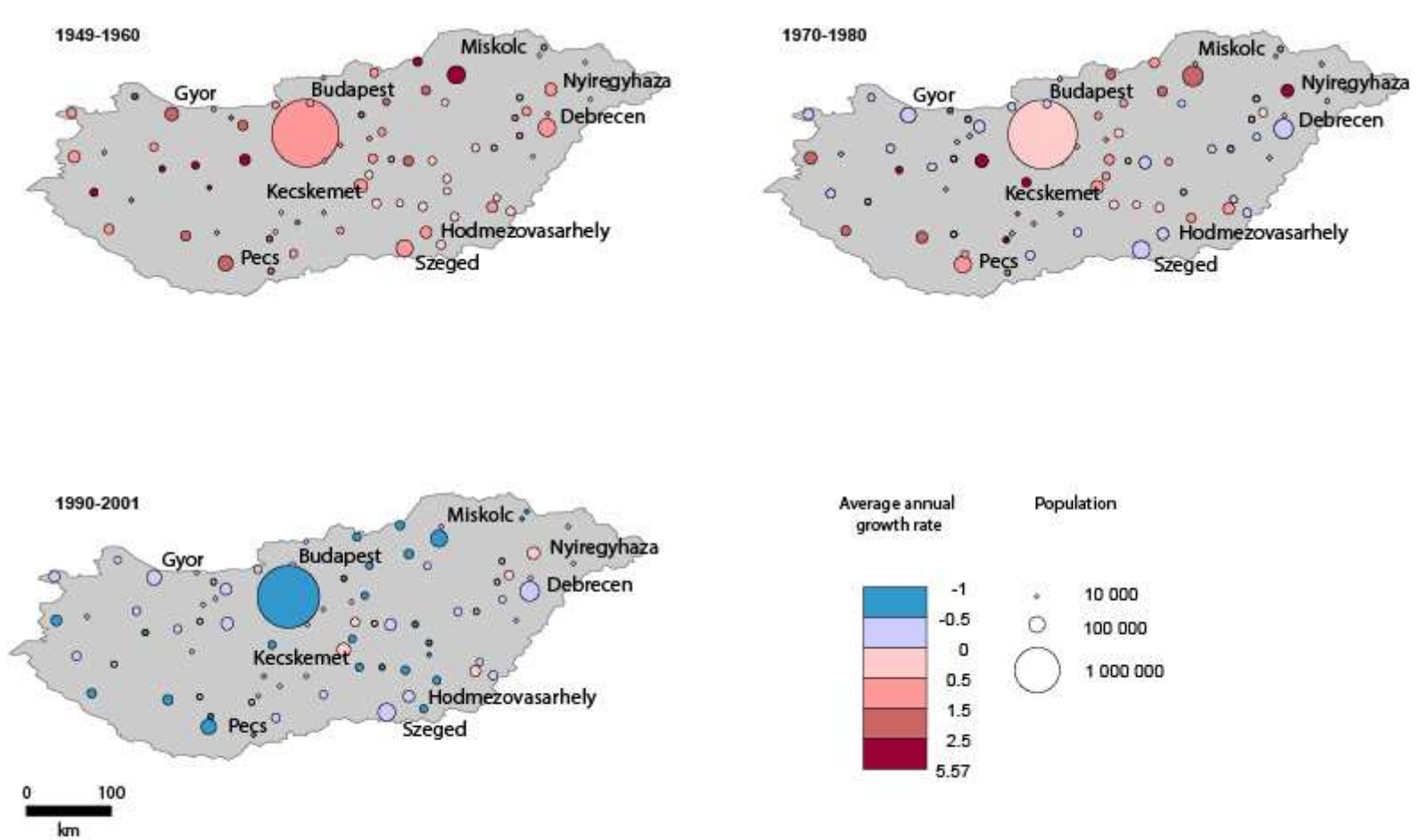

Databases: Urban Morphological Zones and Hungarian Statistical Office.

Zdanowska, 2015.

Figure 9 confirms the spatially important disproportion in size between the capital city of Budapest and the other medium sized cities. They form a "half-ring" around the capital and are located in different parts of the country along its borders (Kiss, 2004). In terms of growth of population we can point out the positive average annual growth rate of practically all the cities between 1950-1960; the beginning of negative growth in cities such as Gyor, Debrecen or Szeged between 1970-1980; and a negative average annual growth rate covering all the territory in the 1990s.

This massive decline can be firstly explained by very low fertility rates and the demographics of an ageing society from 1980 onwards (Kovács, 2004). The natural decrease of population was particularly occurring in Budapest and Western Hungary. In the Eastern part, fertility rates were higher because of cultural factors in the rural areas (specifically the tradition of large families amongst the Greek Catholics and Roma populations) (Kovács, 2004). A second reason might be an important ethnical migration to the West and a displacement of labour forces, particularly to Germany, after the collapse of communism in 
1989 (United Nations, 2002). The important decline of population in Budapest and other big cities in the 1990s can also be explained by a rapid suburbanisation process (Kovács, 2004).

The city of Miskolc is a typical case of an important industrial city during socialism, which in the 1950s developed an increasing population because of the attraction of labour to new working places (Kiss, 2004). Since the 1990s, after the closure of the majority of the industrial parks in Miskolc, the area concerned was dealing with important losses of population and some average re-settlement of ethical minorities that moved there from Romania (Hárs et al., 2001).

\section{Poland}

Figure 10 Average annual growth rate of the Polish retropolated UMZ of more than 10,000 inhabitants between 1950 and 2002
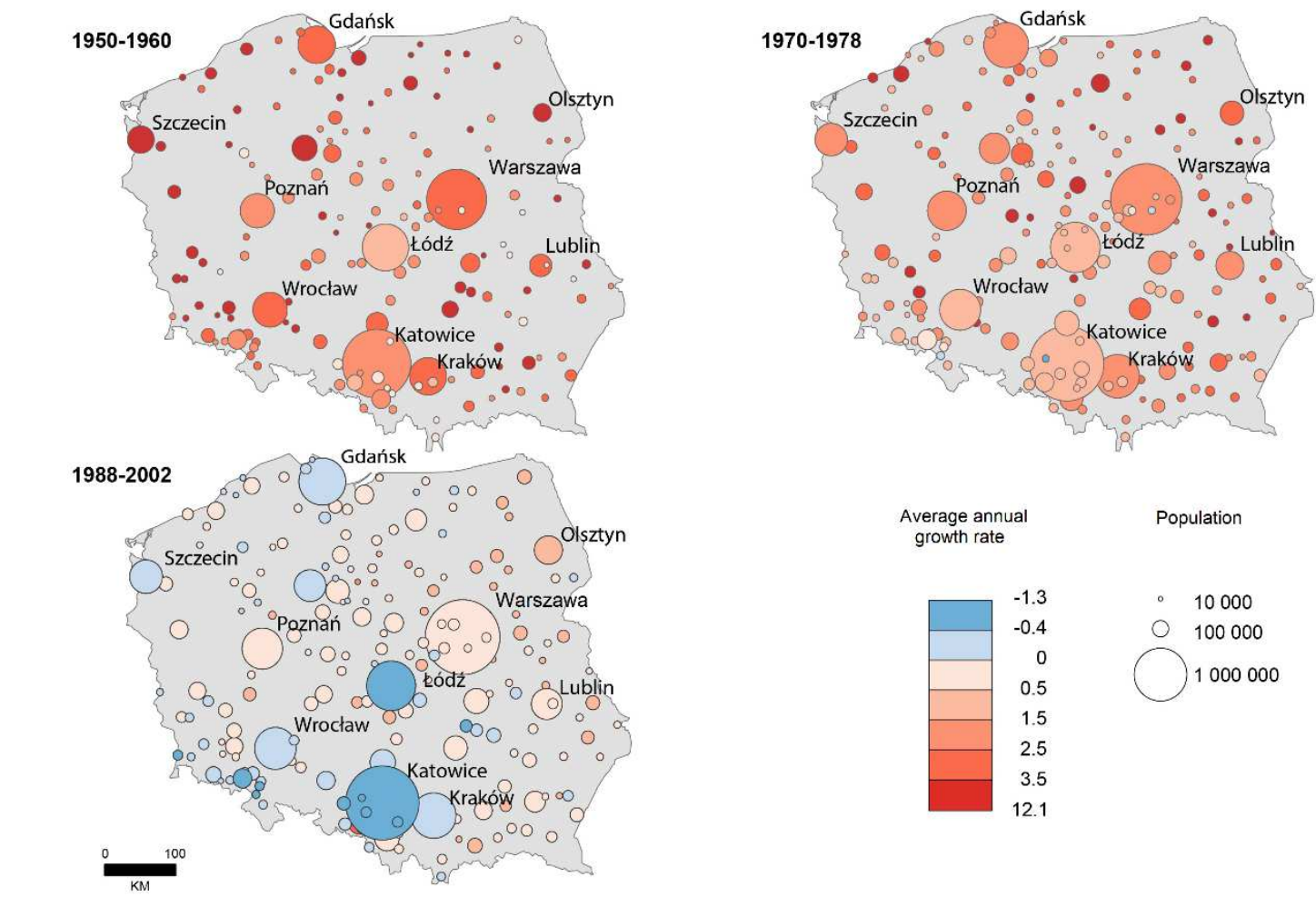

Figure 10 reveals an imbalanced system of cities between the East and West of the country in terms of the repartition of big cities. Apart from Warsaw, there are very few medium sized cities in the Eastern part of the country. This configuration can be explained by the partition of Poland between the Austrian, Prussian and Russian Empires in the $18^{\text {th }}$ and $19^{\text {th }}$ century, leading very different sets of urban politics (Trzeciakowski, 1981). However, the more 
important growth rate of the cities in the Eastern part of Poland between 1988 and 2002, contributes to the idea of a more equilibrated system in terms of urban hierarchy. In fact these cities were not affected by the industrial crisis of the 1990s and shifted more rapidly to the services' sector era (Węcławowicz, 2010). Large industrial cities steeped in socialism as the Katowice Conurbation and Łódź, have experienced a decline since the 1980s, announcing the decadence of the regime and its collapse in 1989 (Węclawowicz, 2010). Numerous inhabitants of the cities from the Katowice Conurbation have decided to move to Cracow because of environmental issues and began commuting over $50 \mathrm{~km}$ to work every day instead (Węcławowicz, 1996). Furthermore, the explanation for the decline of the cities in the Western part of Poland lies in the emigration of the ethnic minorities of German origin from the Upper and Lower Silesia regions (Gdańsk and Szczecin) to Germany (Okulski, 1996; Nowosielski, 2012) after 1989. Germany registered at least a quarter of a million of immigrants of this kind from Poland (Stoła, 2001). The fall of the Berlin Wall was also a moment of intensification of immigration from Poland, with the aim of finding better employment prospects, which had already started in the 1980s mainly in the direction of West Germany (Korcelli, 1992; Stoła, 2001). Indeed at the beginning of the 1990s, Poland had experienced the highest rates of migration among the Soviet satellites of Central Europe, as Czechoslovakia and Hungary had a more restrictive emigration policy (Stoła, 2001). We also have to keep in mind that the institutions at that time were not prepared to register the influx into Poland of labour migration from Asia and the former Soviet countries (KrywultAlbańska, 2011; Stoła, 2001), which is subsequently not reflected in the statistics of this period and consequently in figure 10.

Therefore, an analysis of the hierarchy and urban pattern in the Czech Republic, Hungary and Poland gives evidence of a rather unbalanced system of cities in the Czech Republic and Hungary and a relatively equilibrated system of cities in Poland in terms of urban structure. Nevertheless it is permitted to confirm that Prague, Brno, Ostrava, Budapest, Warsaw, the Katowice Conurbation, Cracow, Poznań, Gdańsk-Gdynia-Sopot, Wrocław, Lódź and Lublin, are considered today as metropolises by the OECD, and have always been important urban areas of these three nations systems of cities since 1950 .

To summarize, it is important to point out that at the collapse of communism, the Czech Republic, Hungary and Poland had very different settlement structure inherited from the state socialism, but also differing historical background (Enyedi, 1998). They also jettisoned markedly differing sets of primary skills to initiate the shift to a market economy (Sucháček, 2014). For example, in Hungary and Poland private ownership was partially permitted, which 
was strictly not the case in Czechoslovakia (Sucháček, 2014). These different backgrounds can also provide a hint into understanding their current development.

\section{CONCLUSION AND DISCUSSION}

The objective of this article was to put into perspective the metropolisation phenomena in the Czech Republic, Hungary and Poland and the dynamics of their system of cities since 1950.

After presenting the methodology of the construction of a database on morphological agglomeration in the Czech Republic, Hungary and Poland since 1950, the first step was to analyse urban hierarchy and urban patterns in these three countries. It permitted us to point out an evolution towards a less pronounced urban hierarchy in the Czech Republic since 1970 until 2001, a system with growing inequalities in Hungary in the last fifty years and a longterm tendency to less inequalities between cities in Poland from 1950 until 2001. The Polish system of cities was the only one among the three analysed countries to present an evolution towards polycentricity in terms of its urban pattern since 1950. On the contrary, the Czech Republic and Hungary have been characterised by an important predominance of the capital on the other cities for the last 50 years.

These results show that in spite of the common socialist past between 1950 and 1989, the Central European system of cities has evolved in a very heterogeneous way which can be verified in the cases of the Czech Republic, Hungary and Poland. Consequently these three countries entered the transition period characterised by these different configurations.

We are aware that an analysis based on a morphological definition of a city is not the only alternative and by far not the most perfect one. Additionally the selection of a unique criterion of delimitation for all Central European countries for the retropolation is a considerable challenge. Nevertheless, in our case the Urban Morphological Zones of 2000 database gives us the unique possibility to make a long-term analysis of the evolution of Czech, Hungarian and Polish urban systems with one homogeneous definition of urban units since 1950.

Parallely to the analysis presented in this article, we have investigated the firms' location in these three countries since the 2000s (from 1995 in the Czech Republic) ${ }^{14}$. The results reveal that the concentration of activities has driven extreme inequalities between capital

\footnotetext{
${ }^{14}$ The impact of the economic attractiveness of metropolitan areas on firm location in Central Europe has been investigated using the Hoppenstedt Bonnier with regards to the location of Hungarian firms, their capital in 2014 and the foreign ownership of this capital; the Czech Top 100 in reference to the location of Czech firms and their turnover in 1995, 2000 and 2005 (Sucháček, Baránek, 2012); and the Word Connexions database (Polaczenia Świat) elaborated upon professor P. Śleszyński (Śleszyński, 2007) in terms of the location Polish firms location and foreign owner control of their capital in 2004.
} 
cities and the rest of the urban system in the Czech Republic, Hungary and Poland. The economic maps coincide with the urban settlement maps for recent year, although the population spatial repartition is less hierarchized than is the case regarding firm localisation. Even in the case of Poland which has a relatively equal urban system in terms of population, the location of firms indicates a strong concentration in Warsaw and in only a few other large cities in Poland.

All in all, we can suppose that our hypothesis stipulating that metropolisation since 1989 in Central Europe contributed to raise the predominance of the capital city among the national system of cities level appears to be close to reality. Furthermore, the most interesting point is that the cases of Czech Republic, Hungary and Poland seem to show that this predominance is verified no matter if the urban system was initially more or less equal in terms of urban hierarchy and urban patterns.

Indeed, the role of cities has been crucial in the process of globalisation. It is not surprising that it was those offering the best opportunities that have attracted the headquarters of big international firms and gained international metropolitan functions. In Central Europe, capital cities have been the first to provide this kind of openness towards the Western world. All these interpretations and the role of metropolisation in orientating the spatial dynamics of urban systems in Central Europe are a subject of further analysis in future research.

\section{REFERENCES}

Bourdeau-Lepage, L. (2004, April 23). Varsovie une nouvelle métropole, GaWC Research Bulletin, 142. Retrieved November 2, 2014, from http://www.lboro.ac.uk/gawc/rb/rb142.html.

Bretagnolle, A., Pumain, D., Rozenblat C. (1998, July 10). Space-time Contraction and the Dynamics of Urban Systems. Cybergeo: European Journal of Geography, Dossiers, 10ème Colloque Européen de Géographie Théorique et Quantitative, Rostock, Allemagne, 6-11 septembre 1997, 61. Retrieved March 13, 2015, from http://cybergeo.revues.org/373.

Bretagnolle, A., Pumain, D, Vacchiani-Marcuzzo, C. (2007). Les formes des systèmes de villes dans le monde. In M.-F. Mattei, D. Pumain (Ed.), Données urbaines, 5, (pp. 301314), Paris: Anthropos-Economica.

Bretagnolle, A. (2009). Villes et réseaux de transport: des interactions dans la longue durée (France, Europe, États-Unis), Habilitation à diriger des recherches, 3. Paris: Université Paris 1.

Bretagnolle, A., Le Goix, R., Vacchiani-Marcuzzo, C. (2011). Métropoles et mondialisation, Documentation photographique, 8082. Paris: La Documentation française.

Bretagnolle, A., Giraud, T., Guérois, M., Mathian, H. (2012) A new database for the cities of Europe? Urban Morphological Zones (CLC2000) confronted to three national databases of urban agglomerations (Denmark, France, Sweden). Environment and Planning B, 39 (3), 439-458. 
Cattan, N., Grasland C., (1994). Migrations et effets de barrière en Tchécoslovaquie. In V. Rey (Ed.), La Tchécoslovaquie en 1992: transition, fragmentation, recomposition, Presses de l'ENS Fontenay-Saint-Cloud, collection Sociétés, Espaces, Temps, 97-120.

Cattan, N., Saint-Julien, T. (1998) Modèles d'intégration spatiale et réseau des villes en Europe occidentale. L'Espace géographique, 27, 1-10.

Drbohlav, D. (2003). Immigration and the Czech Republic (with a Special Focus on the Foreign Labor Force), International Migration Review, 37 (1), 194-224.

Dijkstra, L., Poelman, H. (2012). Cities in Europe. The new OECD-EC definition. Regional Focus, RF 01/2012, Regional and Urban Policy. Retrieved January 28, 2015, from http://ec.europa.eu/regional_policy/sources/docgener/focus/2012_01_city.pdf.

Dostál, P. (2008). The Post-Communist Capital City Effects, Transactional Activities and Regional Development in the Czech Republic in the 1990s: a Modelling Approach. In W. Strubelt, G. Gorzelak (Ed.), City and Regions, Papers in honour of Jirri Musil (pp. 15-42). Opladen: Budrich UniPress.

EEA. (2002). CORINE land cover update, Technical guidelines, EEA, 56. Retrieved January 28, 2015, from http://www.eea.europa.eu/publications/technical_report_2002_89.

ESPON project 1.4.3 (2007), Study on Urban Functions, final report, ESPON Monitoring Committee. $\quad$ Retrieved March 7, 2015, from http://www.espon.eu/export/sites/default/Documents/Projects/ESPON2006Projects/Stud iesScientificSupportProjects/UrbanFunctions/fr-1.4.3_April2007-final.pdf.

Enyedi, Gy. (1998). Transformation in Central European Postsocialist Cities. Pecs: Centre for Regional Studies of the Hungarian Academy of Sciences.

Gesano, G., Heins, F. (2008). Regional challenges in the perspective of 2020 regional disparities and future challenges. Rome: ISMERI Europa. Retrieved March 12, 2015, from

http://ec.europa.eu/regional_policy/sources/docgener/studies/pdf/challenges2020/region al_challenges_synthesis.pdf.

Hampl, M. et al. (1999). Geography of Societal Transformation in the Czech Republic, Prague. Prague: Department of Social Geography and Regional Development, Charles University of Prague, Faculty of Science.

Hárs, Á., Sik, E., Tóth, J. (2001). Hungary. In C. Wallace, D. Stola (Ed.), Patterns of Migration in Central Europe, New York: Palgrave, 252-276.

Hungarian Central Statistical Office (2012). Megyei jogú városok (County towns). Retrieved March 19, 2015, from http://www.ksh.hu/docs/hun/xftp/idoszaki/regiok/veszpremmjv10.pdf.

Jakóbczyk-Gryszkiewicz, J. (1998). Przeobrażenia stref podmiejskich dużych miast. Studium porównawcze strefy podmiejskiej Warszawy, Łodzi i Krakowa (Transformation of big cities suburban zones. Comparative study of Warsaw, Łodź, Cracow). Łódź: Wydawnictwo Uniwersytetu Lódzkiego.

Kaczmarczyk, P., Okólski, M. (2005). International migration in Central and Eastern Europe-current and future trends. New York: United Nations expert group meeting on international migration and development.

Kiss, E. (2004). Spatial impacts of post-socialist industrial transformation in the major Hungarian cities. European Urban and Regional Studies, 11 (1), 81-87.

Korcelli, P. (1992). International Migrations in Europe: Polish Perspectives for the 1990s. International Migration Review, 26 (2), Special Issue: The New Europe and International Migration, 292-304.

Kovács, Z. (2004). The socio-economic transition and regional differentiation in Hungary. Geographical Bulletin, LIII (1-2), 33-49. 
Krywult-Albańska, M. (2011). Caught in a Fever? The Social and Economic Background of Emigration from Poland in the 1980s, Polish American Studies, 68 (2), 107-126.

Le Gléau, J.-P., Pumain, D., Saint-Julien, T. (1996). Villes d'Europe: à chacun sa définition. Economie et Statistique, 294-295, 4/5, 9-23.

Michalet, C.-A. (2007). Mondialisation, la grande rupture. Paris: La Découverte.

Moriconi-Ebrard, F. (1994). Géopolis. Pour comparer les villes du monde. Paris: Anthropos, Economica, Collection Villes.

Musil, J. (1993). Changing Urban Systems in Post-communist Societies in Central Europe: Analysis and Prediction. Urban Studies, 30 (6), 899-905.

Nowosielski, M. (2012). Polacy w Niemczech. Stan i perspektywy badan (Poles in Germany. State and perspectives of investigation). Przeglad Zachodni, 3, 1-28.

Ouředniček, M., Špačková, P., Feřtová, M. (2011). Změny sociálního prostředí a kvality života $\mathrm{v}$ depopulačních regionech České republiky (Changes in Social Milieu and Quality of Life of Depopulating Areas of the Czech Republic). Sociologický časopis/Czech Sociological Review, 47 (4), 777-803.

Parliament of Czech Republic, (2000). Předpis č. 128/2000 Sb. Zákon o obcích (Consolidated version of Law no. 128/2000. The Law on Municipalities). Retrieved March 19, 2015, from http://www.zakonyprolidi.cz/cs/2000-128.

Parr, J. B. (2007). Spatial definitions of the city: four perspectives. Urban Studies, 44, 381392.

Peeters, D. (2011). The Functional Urban Areas Database, Technical Report, ESPON. Retrieved January 28, 2015, from http://www.ums-riate.fr/Webriate/wpcontent/uploads/2014/04/DB_TR-FUAs.pdf.

Pumain, D. (2007). Lois d'échelle et mesure des inégalités en géographie. Revue européenne des sciences sociales, XLV, 2007/3, 55-65.

Pyka, R. (2011, December 31). La métropolisation en Pologne: le fonctionnement et l'avenir des espaces métropolitains polonais, Métropoles, 10. Retreived December 4, 2014, from http://metropoles.revues.org/4515.

Rozenblat, C., Pumain, D. (2007). Firm linkages, innovation and the evolution of urban systems. In P. J., Taylor, et al., Cities in Globalization. Practices, policies and theories (pp. 130-156). London: Routledge.

Sassen, S. (1991). The Global City, Princeton, NJ: Princeton University Press.

Śleszyński, P. (2007). Gospodarcze funkcje kontrolne $w$ przestrzeni Polski (Economical control functions in the Poland's space), Warszawa: Instytut Geografii i Przestrzennego Zagospodarowania, Polska Akademia Nauk.

Stoła, D. (2001). Poland. In C. Wallace, D. Stola (Ed.), Patterns of Migration in Central Europe, New York: Palgrave, 252-276.

Sucháček, J. (2005). Regional Decline and Restructuring in Ostrava Agglomeration and Katowice Conurbation, $45^{\text {th }}$ Congress of the European Regional Science Association, Amsterdam: Vrije Universiteit Amsterdam. Retrieved March 17, 2015, from http://www.ekf.vsb.cz/export/sites/ekf/projekty/cs/weby/esf-0116/databazeprispevku/clanky_ERSA_2005/200.pdf.

Sucháček, J., Baránek, $\bar{P}$. (2012). Largest enterprises in the Czech Republic: a spatio-temporal perspective. Acta Universitatis Agriculturae et Silviculturae Mendelianae Brunensis, LX, 7, 329-336.

Sucháček, J. (2014). Regional Development in Central and Eastern Europe: A New Approach. Actual Problems of Economics, 106-115.

Taylor, P. J. (2004). World city network: a global urban analysis. London: Routledge. 
Trzeciakowski, L. (1981). Ziemie polskie pod panowaniem państw zaborczych (1815-1918), \{Polish territories under occupying countries governance (1815-1918)\}. In J., Topolski (Ed.), Dzieje Polski (Polish history) (pp. 445-610). Warszawa: PWN.

United Nations. (2002). International Migration from Countries with Economies in Transition: 1980-1999. New York: Population Division Department of Economic and Social Affairs United Nations Secretariat.

Vandermotten, C., Vermoesen, F., De Lannoy, W., De Corte, S. (1999). Villes d'Europe. Cartographie comparative. Bulletin du Crédit Communal, $\mathrm{n}^{\mathrm{o}}$ 207-208.

Vandermotten, C., Marissal, P., Van Hamme, G. (2010). La production des espaces économique. La formation du système-monde, 1. Bruxelles: Université Libre de Bruxelles.

Węcławowicz, G. (1996). Contemporary Poland: space and society. London: UCL Press.

Węcławowicz, G. (2010). Charakterystyka głównych trendów i zmian w rozwoju obszarów miejskich Polski (Characteristics of the main tendencies and changes in development of urban zones in Poland). Warsaw: Ministerstwo Rozwoju Regionalnego, Departament Koordynacji Polityki Strukturalnej.

Zborowski, A. (2009). Zmiany zasięgu oddziaływania miast w Polsce w okresie transformacji systemowej, na przykładzie dojazdów do pracy (Changes of cities' influence zones in Poland during the system transformation period, on the example of commuters). In Z., Górka, A., Zborowski (Ed.), Człowiek i rolnictwo (pp. 249-263), Kraków: Instytut Geografii i Gospodarki Przestrzennej, Uniwersytet Jagielloński. 